\title{
MENTORING IN TEACHING PROFESSION
}

\author{
Dr. Sonja Petrovska, Faculty of Educational Sciences, Goce Delcev University, Stip, Republic of Macedonia \\ E-mail: sonja.petrovska@ugd.edu.mk \\ Dr. Despina Sivevska, Faculty of Educational Sciences, Goce Delcev University, Stip, Republic of Macedonia \\ E-mail: despina.sivevska@ugd.edu.mk \\ Dr. Biljana Popeska, Faculty of Educational Sciences, Goce Delcev University, Stip, Republic of Macedonia \\ E-mail: biljana.popeska@ugd.edu.mk \\ Dr. Jadranka Runcheva, Faculty of Educational Sciences, Goce Delcev University, Stip, Republic of Macedonia \\ E-mail: jadranka.runceva@ugd.edu.mk
}

A R T I C L E I N F O

Original Research

Received: Mart, 29.2018.

Revised: June, 07.2018.

Accepted: July, 06.2018.

doi:10.5937/ijcrsee1802047P

UDK

371.213 .3

$371.13 / .15$

Keywords:

novice teachers,

teacher-mentor,

professional development,

Republic of Macedonia.

\begin{abstract}
A B S T R A C T
Mentoring as a form of strengthening the competencies of teachers is widely accepted in the educational system of the Republic of Macedonia. Generally, experienced teachers and those who are new perceive this process as inevitable for strengthening and retaining quality staff. The goal is to explore what teachers think about mentoring novice teachers in teaching. In line with the stated goal, we tried to answer the following questions: Are there differences in teachers' views and opinions about the mentoring process regarding their work experience? Does mentoring as a process contribute to/ for teachers' professional development? Are there differences in views and opinion of teachers for the mentoring process regarding their experience and involvement in the mentoring of novice teachers? The obtained results pointed to the weaknesses that the mentoring process in our country is facing with. Although mentoring as a process is regulated by law, in practice there are still inconsistencies in its realization, both from the aspect of the approach and from the aspect of effectiveness. The recommendation to schools is to try, in addition to mentoring, to offer other forms of support to novice teachers and to try to support the teaching profession through a continuous investment (staff and financial).
\end{abstract}

(C) 2018 IJCRSEE. All rights reserved.

\section{INTRODUCTION}

Mentoring is a complex, interactive process that takes place between people with different levels of experience and expertise, in which the expert (mentor) gives support to his colleague in order to become more efficient in the work and to contribute to the achievement of the goals of the institution in which he works. The ultimate goal of this process is professional development and career advancement (According to Carmin, 1988, as cited in Hester and Setzer, 2013). The mentoring process is an integral part of every sphere of life and work. Through this process: the general and specific work competencies of the mentee

Corresponding Author

Dr. Sonja Petrovska, Faculty of Educational Sciences, Goce Delcev University, Stip, Republic of Macedonia E-mail: sonja.petrovska@ugd.edu.mk

\section{cc) (†) $\ominus$}

This work is licensed under a Creative Commons Attribution - NonCommercial - NoDerivs 4.0. The article is published with Open Access at www.ijcrsee.com are being promoted, emotional support is given and the knowledge, skills and experience of the mentor are transferred to the mentee, and this indirectly improves the quality of work in the institution itself.

Mentoring as a process has always existed in the sphere of education, regardless of the form in which it came through time (formal or informal). In the educational sphere, main participants in the mentoring process are the experienced teacher (teacher - mentor) and the beginner teacher - novice teacher, who mutually share knowledge, skills and experience. Essentially, this type of targeted interaction helps beginner teachers to become successful in their profession and to improve the results of their work in the long run (Ingersoll and Kralik, 2004). There is also research evidence that mentoring affects positively in terms of improving professional and vocational performance not only among novice teachers, but also among experienced teachers (WashburnMoses, 2010).

Mentoring as a form of strengthening the competencies of teachers is widely accept- 
ed in the educational system of the Republic of Macedonia. Generally, the experienced teachers and those who are new perceive this process as inevitable to strengthen and retain quality staff. The mentoring process helps beginner teachers in a way that it facilitates the process of transition from studies to practice and helps them to turn the potential failure into success, and on the other hand, this process provides children with quality teaching. The value of the mentor is of great importance, but at the same time, the benefit that the mentor has in the process is important.

By definition, a mentor is an expert with experience that helps less experienced colleagues in further development of their competences (Directions for mentoring and following the individual work of students, 2017). In this process, the mentor tries to improve the skills of the novice teacher, skills that are already developed at the mentor itself. The role of the teacher - mentor is to help the novice teacher successfully pass the first year of his working experience as a teacher, through dedicated time to monitor, giving feedback, transferring good practices and leading conversations, acquiring professional experience, but also building views and values important in the teacher's profession (Ristovska et. al., 2016 , p. 8). The whole process implies that there is a partnership between the mentor and the mentee. The novice teacher should see itself as a partner and colleague of his mentor. Throughout their cooperation, the mentor and the mentee should be guided by the following principles: confidentiality, availability, openness, optimism, efficiency, respect. A good mentoring process is characterized with: good planning, continuity, monitoring and feedback, reflexivity. The success of this process depends on the established relationship and collaboration between the mentee and the mentor (Ristovska et. al., 2016).

The people who serve as mentors are the foundation of any mentoring program. The quality of this foundation is determined by the way a district or school approaches three key program elements: Mentor Selection Criteria, Continuous Mentor Growth, Human Capital Structure (Educator Effectiveness, January 2018 - Mentoring New Teachers, p. 2).

Benefits from the mentoring process have all stakeholders: novice teachers, mentors and the school itself.

Benefits for the novice teachers are:

- He will become more secure in what he does and he will perform the teaching more competently, he will create a good working at- mosphere in the classroom and he will create a good relationship with students, teachers and parents;

- He will learn to learn, to promote professional practice through learning from multiple sources and different approaches, exchange experiences and opinions with the mentor and other colleagues;

- He will acquire reflective skills for self-evaluation of the work and for using such knowledge to promote his own work;

- He will be introduced in the planning of its own professional development

- He will feel safer and more prepared for taking the professional exam

Benefits for the mentors are:

- To receive information about their own skills and on the basis of it to improve their own competencies;

- To enrich his professional experience and to develop professionally;

- To acquire the mentoring competencies necessary for advancement in the advisor's position.

Benefits for the school are:

- Gets professionally trained staff;

- Development of school culture;

- Upgrading and improving the skills and knowledge of the existing teaching staff;

- Interaction and cooperation between the staff (Ristovska et al. 2016, p. 11; Stevanovska, 2012).

\subsection{System of mentoring in Republic of Macedonia}

In Republic of Macedonia, the mentoring process of new teachers in schools is regulated with the primary and secondary education laws, as well as with other bylaws.

Teachers who enter the educational process for the first time go through several stages, starting with monitoring mentor's work, realization of teaching under mentorship, to self-realization of what he has learned.

There are four categories and levels of jobs for employees - teachers in primary and secondary schools in the Republic of Macedonia, these are novice teacher, teacher, teacher - mentor and teacher - advisor (Primary Education Law. Consolidated text p. 32; Secondary Education Law. Consolidated text p. 30).

The teacher progresses, moving one level to another, gaining the appropriate title: 
from novice teacher, teacher, through teacher mentor level, up to teacher - advisor. The Minister on the proposal of the Bureau of Education and Science and the Center for Vocational Education and Training prescribes the professional standards and method of acquisition of the titles teacher - mentor and teacher - advisor (Law for teachers in primary and secondary schools. Consolidated text p. 8).

A novice teacher is a person, who is employed for the first time in primary, i.e. public secondary school (Primary Education Law. Consolidated text, p. 35; Secondary Education Law. Consolidated text, p. 33). Teacher's apprenticeship starts from the entry of the teacher-beginner in the classroom and lasts for one year. The novice teacher has his own mentor (a teacher appointed by the principal who teaches the same or affined subject with the novice teacher) from whom he learns throughout this entire period. During the apprenticeship period, the novice teacher with the help of his mentor works to strengthen the following six segments: knowledge about the subject and the educational system, teaching and learning, creating a stimulating learning environment, social and educational inclusion, communication and cooperation with family and community and professional development and professional cooperation (Tasevska, Stojanov and Mickovska, 2016, p. 13).

Novice teacher who has completed non-teaching studies is also obliged to attain apprenticeship, before taking the vocational exam, and before that, he must pass the pedagogical-psychological and methodical preparation (pedagogical qualification). This pedagogical qualification encompass passing the examinations of pedagogy, psychology, teaching methods, two elective subjects (from the list of offered elective subjects) and to realize 45 day practice in school (Regulations for manners of following of the teaching process, exams for pedagogic, psychologic and methodic preparations, Official Gazette of the Republic of Macedonia, 56/2014).

Teacher-mentor is a teacher who: must have at least 5 years of working experience as a teacher; at the last conducted integral evaluation, his work as a teacher should be evaluated with not less than four (4); and these teachers should satisfy a certain minimum of points for achieving the professional standards for teacher-mentor (points for teacher promotion can be received for: professional development, professional practice, professional cooperation and cooperation with family and community) (Law for teachers in primary and secondary schools. Consolidated text p.1-9). For promotion in the title teacher-mentor, it is not enough just to be excellent teacher, expert in your field, but these teachers need to prove that they are leaders in the school and that from their engagement the whole collective in the school has a benefit (Tasevska, Stojanov and Mickovska, 2016, p. 39).

The mentor of the novice teacher is determinated by the school principal, from the ranks of teachers i.e., the professional associates or educators who perform the work for which the novice teacher is trained and have the title teacher - mentor or teacher - advisor (Primary Education Law. Consolidated text, $p$. 35; Secondary Education Law. Consolidated text, p. 33).

\subsection{Duties of the teacher - mentor}

The mentor needs to work with the mentee to establish an input-output process which is functional and sophisticated (Guide to mentoring, 2012, p. 8). The teacher-mentor has numerous responsibilities, and part of the duties related to the mentoring process of the novice teachers are (Primary Education Law. Consolidated text, p. 35; Law for teachers in primary and secondary schools. Consolidated text, p.11; https://educiranje.wordpress.com):

- To prepare a program that includes methodical, didactical and other preparation needed to train the teacher and for taking the exam; er work;

- Prepares a report for the novice teach-

- Participates in the preparation of the school's development policies and performs other tasks in accordance with the acquired competencies for a teacher-mentor;

- To detect the initial needs of the novice teachers related with the first teaching classes and with the behavior towards students and parents, through timely holding meetings;

- To inform the novice teacher that he as a mentor is here for him and that he is free to contact him and ask for everything that interests him and is related to the teaching profession;

- To help him in the process of acquainting and acceptance. To create conditions the novice teacher to be treated as a professional by other teachers in the school collective;

- The novice teacher can come up with fresh ideas and knowledge related to the educational activity. The mentor should help him to put those ideas and knowledge into action, 
i.e., their successful realization, of course, if they are good and applicable, not to neglect them and suppress them without giving him a chance to see how they would function and could be applied in practice.

\subsection{Monitoring and evaluation of teachers work}

Every three years, the State Educational Inspectorate performs integral evaluation of the educational work legality in the school and individually evaluate each teacher and professional staff. For teachers who plan to progress in higher title, it is very important to get a grade 4 or 5 by the State Educational Inspectorate, by which they will be entitled to apply for promotion to a higher title (Tasevska, Stojanov and Mickovska, 2016, p. 15). Recently (besides State Educational Inspectorate), the Bureau for Development of Education is in charge of monitoring the work of the teachers and professional staff, and will also play an important role in the assessment of the teachers because of their progress in the title teacher-mentor and teacher-advisor (Tasevska, Stojanov and Mickovska, 2016, p.16).

\subsection{Financing}

Apprenticeship lasts for one year. During the apprenticeship, the novice teacher is paid a salary equal to $80 \%$ of the salary of the teacher, of the professional staff, or the educator. During the apprenticeship, the mentor follows the novice teacher. For the mentor's work, the school pays a fee to the mentor in the amount of $10 \%$ of the salary that the novice teacher will receive after completion of the apprenticeship (Primary Education Law. Consolidated text, p. 35).

\section{MATERIALS AND METHODS}

Subject of this research are views and opinions of the teachers from primary and secondary schools in Republic of Macedonia, regarding the process of mentoring novice teachers in the teaching process and how it contributes to teacher's professional development.

The purpose of the research is to discover what teachers with different work experience, as well as teachers who have experience in mentoring novice teachers, think about the process of mentoring novice teach- ers in teaching. In line with our goal, we tried to answer the following questions:

1. Are there differences in teacher's views and opinions for the mentoring process, regarding their work experience?

2. Does mentoring as a process contribute to/for teacher's professional development?

3. Are there differences in teacher's views and opinions for the mentoring process, regarding their experience and involvement in the process of mentoring novice teachers?

The sample consists 398 teachers (primary and subject teachers) from 28 city primary and secondary schools with approximately equal material-technical working conditions and with approximately equal social structure of students. Of these, $73.9 \%$ are female and $25.1 \%$ male. According to work experience, most of the teachers are with work experience of $6-15$ years $(37.7 \%), 21.6 \%$ have work experience over 25 years, $19 \%$ have work experience of 16-25 years and $16.8 \%$ with work experience of 1-5 years. According to the working position, $40.2 \%$ are primary school teachers, $34.2 \%$ are subject teachers in secondary school and $24.6 \%$ are subject teachers in primary school. Of the total number of respondents, $39.5 \%$ have been mentors of novice teachers.

Presented results are only one part of the project "Professional Development of Teachers in the Republic of Macedonia - Conditions and Challenges", realized within the Faculty of Educational Sciences, Goce Delcev University in Stip, Republic of Macedonia, 2016-2018. The goal of the project is to study the position and function of the system for teacher's professional development in Republic of Macedonia, analyzing: the pedagogical-organizational setup of the system for teacher's professional development; teacher's views and opinions regarding the functionality and applicability of the established system for professional development and their expectations from the institutions regarding this issue; factors that influence on the motivation for professional development; forms for professional development of teachers; individual needs for the type, manner and content of the professional development; satisfaction from their own level of professional development, as well as comparison with other models of professional development and proposal of a new national model.

For the purpose of the research, a survey questionnaire is used. In addition to the basic data (school, gender, position of the school, current position of the teachers, work experi- 
ence, educational level) the questionnaire also contains, closed-type questions - an assessment scale where the teachers determine the level of agreement and satisfaction with the offered claims.

The obtained results are analyzed and presented using the descriptive statistics: frequencies (f), percentage (\%), and non-parametric procedure: analysis of variance (f-test) and t-test. The data obtained from the survey are processed using the statistical package SPSS 19.

\section{RESULTS}

Table 1. Difference between views of the teachers with different work experience, regarding the mentoring process of the novice teachers (ANOVA)

\begin{tabular}{|c|c|c|c|c|c|c|}
\hline \multicolumn{7}{|c|}{ ANOVA } \\
\hline & & $\begin{array}{l}\text { Sum of } \\
\text { Squares }\end{array}$ & $\mathrm{df}$ & $\begin{array}{l}\text { Mean } \\
\text { Square }\end{array}$ & $\mathrm{F}$ & Sig. \\
\hline \multirow{3}{*}{$\begin{array}{l}\text { Mentoring novice teachers and } \\
\text { students - future teachers contributes } \\
\text { to the professional development of the } \\
\text { teachers }\end{array}$} & Between Groups & 7,572 & 5 & 1,514 & \multirow{3}{*}{3,508} & \multirow{3}{*}{, $004 * *$} \\
\hline & Within Groups & 168,786 & 391 & 432 & & \\
\hline & Total & 176,358 & 396 & & & \\
\hline \multirow{3}{*}{$\begin{array}{l}\text { According to you, the way of } \\
\text { realization of the mentoring process } \\
\text { of the novice teachers in your school, } \\
\text { contribute to the professional } \\
\text { development of the mentor teachers. }\end{array}$} & Between Groups & 19,234 & 5 & 3,847 & \multirow{3}{*}{3,077} & \multirow{3}{*}{, $010^{*}$} \\
\hline & Within Groups & 488,801 & 391 & 1,250 & & \\
\hline & Total & 508,035 & 396 & & & \\
\hline \multirow{3}{*}{$\begin{array}{l}\text { Mentor teachers should be specially } \\
\text { trained for mentoring. }\end{array}$} & Between Groups & 16,737 & 5 & 3,347 & \multirow{3}{*}{4,935} & \multirow{3}{*}{, $000 * *$} \\
\hline & Within Groups & 265,228 & 391 & 678 & & \\
\hline & Total & 281,965 & 396 & & & \\
\hline \multirow{3}{*}{$\begin{array}{l}\text { Potential teachers should spend the } \\
\text { apprenticeship in the same classroom } \\
\text { with their mentor }\end{array}$} & Between Groups & 8,243 & 5 & 1,649 & \multirow{3}{*}{2,647} & \multirow{3}{*}{, $023 * *$} \\
\hline & Within Groups & 243,490 & 391 &, 623 & & \\
\hline & Total & 251,733 & 396 & & & \\
\hline \multirow{3}{*}{$\begin{array}{l}\text { The school, apart from mentoring, } \\
\text { should offer other forms of special } \\
\text { support to novice teachers }\end{array}$} & Between Groups & 6,312 & 5 & 1,262 & \multirow{3}{*}{4,937} & \multirow{3}{*}{, $000 * *$} \\
\hline & Within Groups & 99,990 & 391 &, 256 & & \\
\hline & Total & 106,302 & 396 & & & \\
\hline \multicolumn{7}{|c|}{ According to which criteria in your school, the mentors for the novice teachers have been chosen? } \\
\hline \multirow{3}{*}{ Teachers quality } & Between Groups & 15,944 & 5 & 3,189 & \multirow{3}{*}{2,333} & \multirow{3}{*}{, $042^{*}$} \\
\hline & Within Groups & 399,080 & 292 & 1,367 & & \\
\hline & Total & 415,023 & 297 & & & \\
\hline \multirow{3}{*}{$\begin{array}{l}\text { According to the principal's } \\
\text { preference }\end{array}$} & Between Groups & 21,692 & 5 & 4,338 & \multirow{3}{*}{2,760} & \multirow{3}{*}{, $019^{*}$} \\
\hline & Within Groups & 446,363 & 284 & 1,572 & & \\
\hline & Total & 468,055 & 289 & & & \\
\hline
\end{tabular}


(IJCRSEE) International Journal of Cognitive Research in Science, Engineering and Education Vol. 6, No. 2, 2018.

Table 2. Differences in the views and opinions among teachers who were and were not mentors for novice teachers in relation to the process of mentoring novice teachers (t-test)

\begin{tabular}{|c|c|c|c|c|c|c|c|c|}
\hline Mentors & & $\mathrm{N}$ & Mean & $\begin{array}{l}\text { Std. } \\
\text { Deviation }\end{array}$ & $\begin{array}{l}\text { Std. } \\
\text { Error } \\
\text { Mean }\end{array}$ & $\mathrm{T}$ & Df & $\begin{array}{c}\text { Sig. } \\
\text { (2-tailed) }\end{array}$ \\
\hline \multirow{2}{*}{$\begin{array}{l}\text { Mentor teachers haven't developed } \\
\text { social skills for mentoring }\end{array}$} & да & 131 & 2,71 & 1,154 &, 101 & \multirow{2}{*}{2,469} & \multirow{2}{*}{307} & \multirow{2}{*}{, $014 * *$} \\
\hline & не & 178 & 2,38 & 1,188 &, 089 & & & \\
\hline \multirow{2}{*}{$\begin{array}{l}\text { Mentor teachers financially are not } \\
\text { motivated enough to carry out this task }\end{array}$} & да & 130 & 2,07 & 1,129 &, 099 & \multirow{2}{*}{$-3,818$} & \multirow{2}{*}{298} & \multirow{2}{*}{, $000^{* * *}$} \\
\hline & не & 170 & 2,59 & 1,195 &, 092 & & & \\
\hline \multirow{2}{*}{$\begin{array}{l}\text { According to you, the way if realization } \\
\text { of mentoring novice teachers in your } \\
\text { school contributes to the professional } \\
\text { development of mentor teachers }\end{array}$} & да & 157 & 2,09 &, 963 &, 077 & \multirow[b]{2}{*}{$-7,867$} & \multirow[b]{2}{*}{391} & \multirow[b]{2}{*}{, $000 * *$} \\
\hline & не & 236 & 2,94 & 1,105 &, 072 & & & \\
\hline
\end{tabular}

${ }^{*} \mathrm{p}<0.05 * * \mathrm{p}<0.01$

\section{DISCUSSIONS}

\subsection{Teacher's views and opinions in correlation with their work experience}

Differences in responses of the teachers with different work experience are analyzed using the F-test. The influence of the teachers' work experience on teacher's views for the set questions was statistically significant in almost all of the analyzed answers. This leads to the conclusion that teacher's work experience plays an important role regarding the estimation of the mentoring process of novice teachers, and how this process contributes to teacher's professional development. Statistically significant differences are at the level of 0.01 and 0.05 (Table 2).

\subsubsection{Differences in teacher's views and opinions about the mentoring process regarding their work experience}

Major number of teachers $(79 \%)$ agree that the current mentoring system for novice teachers needs to be improved.

For the question, to indicate the weaknesses of the current mentoring process (several views were offered), the surveyed teachers gave the following answers.

Regarding the fact that mentor teachers do not have developed social skills for mentoring, a large percentage $(23.6 \%)$ of teachers do not agree at all with the view that mentor teachers of novice teachers don't have developed social skills for mentoring.

A large proportion of teachers (30.4\%) fully agree that mentor teachers are not always able to follow the classes of the novice teachers, due to obligations in their own classroom. At the same time, a large proportion $(25.4 \%)$ agree that mentor teachers often perceive this role as peripheral in their profession. Regarding the view that mentor teachers are not financially motivated enough to perform this task, $26 \%$ of teachers fully agree, while $17 \%$ agree, which may be the reason why they experience mentoring as a peripheral obligation and do not regularly follow the classes of the novice teachers.

For the question, whether mentor teachers should be trained specifically for mentoring, a large proportion (49\%) of teachers agree that they should be trained, and $35.4 \%$ partly agree that mentor teachers should be specially trained for mentoring. Statistically significant differences at the level of 0.01 on this issue is observed in the responses of novice teachers who agree with this and teachers with working experience of 16-25 years who partially agree with the view that mentor teachers should be specifically trained for mentoring of novice teachers. This corresponds with the recommendations given in the Project for Professional and Career Development of Teachers in Republic of Macedonia (Mickovska et al., 2013) where is express the need for preparation of a manual for preparation of a mentoring program and introduction of mandatory training for mentors.

The selection of the teacher-mentor for the novice teachers should be according to certain criteria. These criteria are noted in the Law for Teachers in Primary and Secondary 
Schools. According to this, we were also interested in the opinion of the teachers included in the sample. For the question where the teachers were asked to determine, according to which criteria the mentors for novice teachers were selected in their schools, several views were offered on which the teachers gave the following answers:

For the offered views, $35 \%$ of the teachers agree that most often as a criterion is taken the principal's preference, the length of the work experience of the teachers (27.6\%), the teacher's cooperation (21.1), and quality of the teachers $(28.6 \%)$. While $37 \%$ of them consider that the in the selection of the teachers, the expressed wish of the teachers is rarest respected.

In some of these views, we have seen that there are statistically significant differences. Namely, they are perceived in the view for teachers'quality, where we found that older teachers (work experience over 25 years) rarely consider that quality is considered as a selection criterion, versus novice teachers who often consider that teachers quality is considered as a criterion for the choice for mentor teacher of the novice teachers.

Statistically significant differences at the level of 0.01 are also perceived in the view according to the principal's preference. Also in this view, the differences are noted/ determined between more experienced teachers (more than 25 years work experience) compared with novice teachers that has less year of working experience. In this regard, more experienced teachers consider that in process of selection of mentor teachers, the preferences of the principal are often used as main criteria for selection. Compared with them, novice teachers consider that such practice is rarely used (Table 1).

Whether novice teachers should spend their apprenticeship in the same classroom with their mentor is an issue in which the largest percentage $(48.7 \%)$ of the respondents partially agree. Statistically significant differences at the level of 0.01 were observed in the responses of teachers with work experience of 16-25 years who partly agree that they should be together, and the novice teachers who agree that they should spend their apprenticeship in the same classroom with their mentor-teachers.

At the end, the teachers were asked for opinion Whether school should offer other forms of special support, in addition to mentoring, as a support to novice teachers? Statistically significant differences at the level of
0.01 were observed in the responses of novice teachers who agreed that the school should offer to novice teachers' support other than mentoring, unlike the rest, older teachers (with work experience over 16 years) who do not agree with that, that the school should offer another form of support.

\subsubsection{Differences in the views and opinions of teachers with different work experience, regarding whether mentoring as a process contrib- utes for/to teachers' professional development}

Regarding the dilemma does mentoring as a process contributes to the professional development of teachers, teachers were asked the following questions: Mentoring novice teachers and future students contributes to the professional development of teachers and According to you, the way of mentoring novice teachers in your school contributes to the professional development of mentor teachers (Table 1).

In the first question, Mentoring novice teachers and future students contributes to the professional development of teachers, statistically significant differences were noted at the level of 0.01. Differences are noted in the responses of novice teachers who think that it contributes a lot to teachers' professional development, and teachers with 6-15 years' work experience who think that mentoring as a process partly contributes to their professional development.

Statistically significant differences at the level of 0.01 were also observed in the question where teachers were asked to answer whether the way of mentoring novice teachers in your school contributes to the professional development of mentor teachers. The biggest differences were noted among the responses of teachers with 1-5 years' work experience who believe that mentoring process implemented in their school does not contribute to their professional development, unlike older teachers (with work experience of 16-25 years) who consider it partly contributes to their professional development.

This response also corresponds with the remarks noted in the recommendations for improving the mentoring system in the Republic of Macedonia, where it is stated that apprenticeship is not carried out in a systematic way; there are no procedures and instruments for 
promotion in titles and there is no evaluation system for professional development related to the system for promotion in titles. This is an indication that measures need to be taken in order to improve the existing and practicing the already proposed model of mentoring novice teachers, which would contribute to their better inclusion in the school life.

\subsection{Teacher's opinions and attitudes in relation with their experience and involvement in mentoring novice teachers}

Differences in teachers answers regarded their experience and their direct involvement in mentoring of the novice teachers in the teaching process, were analyzed using the t-test. The results that we received, showed statistically significant differences in some of the answers of the questions, that led to the conclusion that teacher involvement in the mentoring process of the novice teacher's influences on their positive attitudes towards mentoring as a process for involving novice teachers in the teaching process, and that this contributes to their professional development. The statistically significant differences are at the level of 0.01 (Table 3).

The results showed that a large proportion of teachers $(79 \%)$ agreed that the current mentoring system for novice teachers should be improved. Regarding the offered statements in which the teachers were asked to indicate the weaknesses of the current mentoring system, we noticed certain differences between teachers. The differences are statistically significant at the level of 0.01 and are seen in the statements: Mentor teachers have not developed social skills for mentoring and Mentor teachers financially are not motivated enough to carry out this task.

Namely, with the statement that teachers have not developed social skills for mentoring agree teachers who have not been mentors until now, while teachers who were mentors disagree with this claim. In the second statement, it is expected that teachers who are mentors of novice teachers agree with the statement that financially are not motivated enough to carry out this task, unlike those who are not mentors who answered that they disagree that they are not financially motivated enough. Perhaps the funds they receive do not correspond with the obligations imposed on them as mentor teachers.
Regarding whether mentoring as a process contributes to the professional development of teachers, we noted that a large proportion of them $(62.6 \%)$ think that mentoring novice teachers partly contributes to the professional development of teachers, and $28.4 \%$ that it contributes a lot.

Statistically significant differences between teachers who were and who were not mentors of novice teachers were obtained on the question in which they were asked to determine whether the way of mentoring novice teachers in their school contributes to the professional development of teachers. Positive attitude regarding this, that it contributes, consider teachers who already have experience in mentoring young future teachers, as opposed to teachers who haven't been mentors, who believed that it does not contributes to the professional development of teachers.

This attitude can be linked with the obligation of mentor teachers to prepare a report on the implementation of the mentoring program and for the achievement of the basic professional competencies of the novice teacher.

After completing the process of mentoring, mentor makes self-evaluation for the work he has done, so this serves for his professional and career development (Ristovska et al., 2016).

\section{CONCLUSIONS}

Mentoring process is of particular importance for teachers who are at the beginning of their careers. Hence, the importance of novice teachers to receive mentor teachers who will be able with their own knowledge, skills and practical experience to introduce novice teachers into teaching profession and school life. Mentoring process creates a number of prerequisites for cooperation between novice teacher and teacher mentor. It is in favor of both the newly appointed teacher who draws experience and ideas from his colleagues as well as from the mentor who, in the framework of working with a new colleague at school, is given the opportunity to make sense of his own pedagogical practices, to analyze a number of situations in the professional sphere, which contributes to the enrichment of his / her professional skills.

The results of our research pointed to the weaknesses that the mentoring process in our country is facing with. Although mentoring as a process is regulated by law, in practice, there are still inconsistencies in its practical imple- 
mentation.

Most teachers agree that in the current mentoring system of novice teachers, changes are needed. They emphasized the need to develop instruments and procedures for career advancement and a system for evaluating professional development, as well as greater financial motivation of mentor teachers, which could be achieved through the development of new financial plans for promotion in titles, which increases awareness of a more serious approach to mentoring as one of the ways for the professional and career development of teacher.

Novice teachers emphasize the need for more frequent contacts with their mentors, the need for greater attendance of the mentor teachers at their classes. Hence, it is recommended that schools, in addition to mentoring, should offer other forms of support to novice teachers and for the state to try to support the teaching profession through continuous investment (staffing and financial).

The main advantage of the research is that it proves that the relationships established between the mentor and the novice teacher are realized in formal and informal structures by supporting both the school leadership and the entire pedagogical team. The established teacher gives a strong start to the young teacher, sharing not only his classroom and extracurricular experience but also his / her skills and attitudes.

In this context, the prospects for our next research on this scientific problem can be directed toward positive practices in the mentoring process, primarily in the countries of the region, and later wider, in order to adopt and implement them in our system.

\section{ACKNOWLEDGEMENTS}

The paper is part of the project "Professional Development of Teachers in the Republic of Macedonia - Conditions and Challenges" (2016-2018), which includes 398 teachers (primary and subject teachers) from 28 primary and secondary schools in Republic of Macedonia.

We would like to address our sincere gratitude to all the teachers who participated in the survey as well as to all principals of primary and secondary schools who that support the organization of this survey.

\section{Conflict of interests}

The authors declare no conflict of interest.

\section{REFERENCES}

Educator Effectiveness, January 2018 - Mentoring New Teachers. Retrieved 14 May 2018, from https://www.sreb.org/sites/main/files/file-attachments/mentoring new teachers.pdf

Guide to mentoring. Advice for the mentor and mentee (2012). Retrieved 14 May 2018 from https:// www.atl.org.uk/Images/ATL\%20Guide\%20 to $\% 20$ mentoring $\% 20(\mathrm{Nov} \% 2012)$.pdf

Hester, J. P., \& Setzer, R. (2013). Mentoring: Adding value to organizational culture. The Journal of Values-Based Leadership, 6(1), 4. Retrieved on 20 June 2018 from https://pdfs.semanticscholar. org/870e/24a74fbb4ad110cae3f283aa7fd8ffdd3 f7c.pdf

Ingersoll, R., \& Kralik, J. M. (2004). The impact of mentoring on teacher retention: What the research says. http://www.environmentalconclusions. com/resources/WORKSHOP 3 - OPTIONAL - Houston - The Impact_of $\overline{\text { Mentoring }}$ on Teacher Retention.p.pdf

Менторство и компетенции. Скопје: Центар за управување со промени, 2016.-40 стр.;21 см, Публикацијата е во рамките на проектот: "Поддршка за реформите во јавната администрација". [Mentoring and competences. Skopje: Center for regulating changes. Publication is a part from the project: "Support and reform in public administration. In Macedonian.] Retrieved on 15 March 2018, from http:// www.cup.org.mk/publications/Kompe-tencii3 Mentorstvo\%20i\%20kompetencii.pdf

Mickovska, G., Kondik Mitkovska, V., Georgieva, L., Stamboliev, A \& Reci, B. (2013). Analysis of the policies and practice of professional and career development of teachers in the Republic of Macedonia, Skopje: Macedonian Civic Education Center (MCEC).

Навремена помош на менторот кон наставникот приправник [Timely assistance from the mentor to the novice teacher. In Macedonian.] Retrieved 22 March 2018 from https://educiranje.wordpress.com/2017/1$0 / 27 / \% \mathrm{~d} 0 \% \mathrm{bd} \% \mathrm{~d} 0 \% \mathrm{~b} 0 \% \mathrm{~d} 0 \% \mathrm{~b} 2 \% \mathrm{~d} 1 \% 80 \% \mathrm{~d}-$ $0 \%$ b5\%d0\%bc\%d0\%b5\%d0\%bd\%d0\%b0-\% d $0 \%$ bf $\%$ d $0 \%$ be $\%$ d $0 \%$ bc\% $\%$ d $\%$ be $\%$ d $1 \% 88-\%$ d $0 \%$ bd $\%$ d $0 \%$ b0- $\% \mathrm{~d} 0 \%$ bc $\% \mathrm{~d} 0 \%$ b5 $\% \mathrm{~d} 0 \%$ bd $\%$ d $1 \% 82 \%$ d0\% $\%$ be $\%$ d $1 \% 80 \%$ d $0 \%$ be $\%$ d $1 \% 82-$ $\%$ d $0 \%$ b a $\%$ d $0 \%$ b e $\%$ d $0 \%$ b d $\% \mathrm{~d} 0 \%$ bd $\% \mathrm{~d} 0 \%$ b0\%d $1 \% 81 \% \mathrm{~d} 1 \% 82 \% \mathrm{~d} 0 \%$ b0/

Основни професионални компетенции и стандарди за наставници, Скопје: Македонски центар за граѓанско образование (2016). [Basic professional competences and standards for teachers. In Macedonian.] Re-trieved 22 March 2018 from http://mk.mcgo.org.mk/wp-content/uploads/2013/07/01-Osnovni-profesional-ni-kompetencii-i-standardi-za-nastavnici.pdf

Правилник за начинот на следењето на наставата, полагањето на испитите за педагошко - психолошка и методска подготовка, како и начинот на акредитација на високообразовните установи. Службен 
(IJCRSEE) International Journal of Cognitive Research in Science, Engineering and Education Vol. 6, No. 2, 2018.

весник на PM, 56/2014. [Regulations for manners of following of the teach-ing process, exams for pedagogic, psychologic and methodic preparations. Official Gazette of the Republic of Macedonia, 56/2014. In Macedoni-an.] Retrieved at 5 January, 2018 from http://www. slvesnik.com.mk/Issues/c743963a84074947a2c b1b986bc8d844.pdf

Ristovska, S et al. (2016). Guideline on the manner and form of providing mentoring support to novice teachers and novice student support staff in primary and secondary schools, Skopje: Macedonian Civic Education Center (MCEC).

Smjernice za mentorstvo i praćenje individualnog rada studenta, Poslijediplomski doktorski studij psihologije, Odsjek za psihologiju, Filozofski fakultet, SVEUCILISTE U ZAGREBU (2017). [Directions for mentoring and following the individual work of students, Postdoctoral studies in psychology, Department for psychology, Faculty of philosophy, University in Zagreb. In Croatian.] http://psihologija.ffzg.unizg.hr/uploads/ $\mathrm{fd} / 00 /$ fd00efa805cd3ede58ace0a2948ec021/ Smjernice-za-mentorstvo.pdf

Stevanovska, A. (2012). Factors that influence the mentoring of teaching staff in the workplace introduction, Faculty of Pedagogy, Bitola, Master thesis. Retrieved 20 March 2018 from https:// www.scribd.com/document/130425091/mentorstvo-magisterrska

Tasevska, A., Stojanov, A \& Mickovska, G (2016). A teacher from a beginner to a mentor. Guide for professional and career development of teachers in primary and secondary schools, Skopje: Macedonian Civic Education Center (MCEC).

Washburn-Moses, L. (2010). Rethinking mentoring: Comparing policy and practice in special and general education. Education Policy Analysis Archives/Archivos Analíticos de Politicas Educativas, 18, 32. doi:http://dx.doi.org/10.14507/ epaa.v18n32.2010

Закон за наставници во основните и средните училишта. Консолидиран текст. [Law for teachers in primary and secondary school. Consolidated text. In Macedonian.] Retrieved 9 March 2018 from http://mon.gov.mk/index. php/2014-07-24-06-34-40/zakoni

Закон за основното образование. Консолидиран текст. [Primary Education law. Consolidated text. In Macedonian.] Retrieved 1 March 2018 from http://mon.gov.mk/images/\%D0\% $\% 97 \%$ D0\%B0\%D0\%BA $\%$ D $0 \%$ BE $\%$ D0 $\%$ BD_ $\%$ D $0 \% \mathrm{~B} 7 \% \mathrm{D} 0 \% \mathrm{~B} 0 \% \mathrm{D} 0 \% \mathrm{BE} \% \mathrm{D} 1 \% 81 \% \overline{\mathrm{D}} 0 \%$ BD $\%$ D $0 \%$ BE $\% \overline{\mathrm{D}} 0 \% \mathrm{~B} 2 \% \mathrm{D} 0 \% \mathrm{BD} \% \mathrm{D} 0 \% \mathrm{BE}$ $\% \mathrm{D} 1 \% 82 \% \mathrm{D} 0 \% \mathrm{BE} \% \mathrm{D} 0 \% \mathrm{BE} \% \mathrm{D} 0 \% \mathrm{~B} 1 \%$ D $1 \% 80 \% \mathrm{D} 0 \% \mathrm{~B} 0 \% \overline{\mathrm{D}} 0 \% \mathrm{~B} 7 \% \mathrm{D} 0 \% \mathrm{BE} \% \mathrm{D} \%$ B2\%D0\%B0\%D0\%BD $\%$ D0\%B8\%D0\%B507. pdf

Закон за средно образование. Консолидиран текст. [Secondary Education Law. Consolidated text. In Macedonian.] Retrieved 1 March 2018 from http://mon.gov.mk/images/\%D0\% $\% 97 \%$ D0 $\%$ B $0 \%$ D0 $\%$ BA $\%$ D0 $\%$ BE $\%$ D0 $\%$ BD $\%$ D $0 \% \mathrm{~B} 7 \% \mathrm{D} 0 \% \mathrm{~B} 0 \% \mathrm{D} 1 \% 81 \% \mathrm{D} 1 \% 80 \% \overline{\mathrm{D}} 0 \%$ B5\%D0\%B4\%D0\%BD $\%$ D0\%BE $\%$ D $1 \% 82$ $\%$ D0\%BE \%D0\%BE\%D0\%B1\%D1\%80\% D0\%B $0 \% \overline{\mathrm{D}} 0 \% \mathrm{~B} 7 \% \mathrm{D} 0 \% \mathrm{BE} \% \mathrm{D} 0 \% \mathrm{~B} 2 \% \mathrm{D} 0$ $\%$ B0\%D0\%BD $\%$ D0\%B8\%D0\%B507.pdf 